\title{
THE MICROSTRUCTURE AND PHASE COMPOSITION OF MORTARS FROM THE 17TH CENTURY SACRED BUILDINGS
}

\section{MIKROSTRUKTURA I SKLAD FAZOWY ZAPRAW Z XVII-WIECZNYCH BUDOWLI SAKRALNYCH}

\author{
Zdzisława Owsiak*, Paweł Sobczyński \\ Kielce University of Technology, Poland
}

\begin{abstract}
This work aims to characterize the microstructure of mortars derived from the walls of sacred buildings from the 17th century. The tests were carried out using the X-ray diffraction method, differential thermal analysis and scanning microscopy combined with the analysis of the elemental composition in the micro area. The results of this study show that the materials bonding the elements of the wall in historic buildings are porous sand-lime mortars with an increased binder-to-aggregate ratio, also containing limestone crumbs, fints and feldspars, and fragments of bricks larger than sand particles. The binder is fully carbonated calcium hydroxide, with no pozzolanic additives. The results of the microstructure and phase composition tests of mortars used for bonding wall elements in buildings constructed at the end of the 16th and early 17th centuries can be used to select the composition of mortars used in the renovation and repair of historic buildings.
\end{abstract}

Keywords: mortar, microstructure, XRD, SEM, EDS

\section{Streszczenie}

Celem pracy jest charakterystyka mikrostruktury zapraw pobranych z muru sakralnych budowli XVII-wiecznych. Badania wykonano metoda dyfrakcji rentgenowskiej, termicznej analizy różnicowej oraz mikroskopii skaningowej połaczonej $z$ analiza składu pierwiastkowego w mikroobszarze. Wyniki przeprowadzonych badań wykazaty, że zaprawy taczace elementy muru w budowlach historycznych sa porowatymi zaprawami wapienno-piaskowymi, o zwiększonym stosunku spoiwa do kruszywa, zawieraja także w swoim składzie okruchy skat wapiennych, krzemieni i skaleni oraz fragmenty cegiet o większych rozmiarach niz ziarna piasku. Spoiwo stanowi w petni skarbonatyzowany wodorotlenek wapnia, niezawierający dodatków pucolanowych. Wyniki badań mikrostruktury i składu fazowego zapraw stosowanych do spajania elementów muru w budowlach wznoszonych w końcu XVI i na początku XVII wieku moga postużyć do doboru składu zapraw stosowanych przy renowacji i naprawach budowli historycznych.

Slowa kluczowe: zaprawa, mikrostruktura, XRD, SEM, EDS

\section{INTRODUCTION}

Buildings are designed and constructed to be durable and timeless. In reality, however, historic buildings undergo constant transformations in terms of significance and physical dimension [1]. Under the influence of factors from the external environment, building elements are subject to corrosion processes, and the improvement of their condition requires maintenance efforts [2]. During the conservation, repair or renovation of historic buildings, mortars 
have to be characterized in terms of their mineralogy. Mortars present in historic buildings were used to connect bricks or stones in the wall, as external and internal plasters, floor underlays or decorative mortars [3]. The most common binders in these mortars, until about two centuries ago, were clay, gypsum and lime, which were then replaced with Roman cement, and later with Portland cement, the dominant type of binder in construction today [4]. The variety of historic mortar compositions is exceptionally large and results both from the geographical location and various historical periods [5]. In Poland, the binder in mortars found in historic buildings was mainly lime, often with additions of clay or organic fibres.

One of the elements of historic buildings conservation is the replacement of mortars damaged by time, use and environmental exposure. The main concern is to identify the composition of the mortar to produce a compatible material. The necessary information on the type and content of the binder and aggregate can be obtained from microstructure tests using microscopic methods, and from the phase composition of mortars. The methods for determining the microstructure and phase composition of historic mortars are X-ray diffraction (XRD), optical microscopy, scanning electron microscopy (SEM), thermal methods and infrared spectroscopy $[6,7]$. Proper sample collection and preparation is essential as in the case of historic structures or sites, minimizing destruction and damage is a priority. A combination of several methods should be used to confirm the determination and quantify the mineralogical composition.

This work aims to characterize the microstructure of mortars derived from the walls of sacred buildings from the 17th century. The tests were carried out using the X-ray diffraction method, differential thermal analysis and scanning microscopy combined with the analysis of the elemental composition in the micro area.

\section{MATERIALS AND METHODS}

\subsection{Materials}

The mortar samples were collected during conservation works on the walls of sacred buildings. The samples analysed in this study come from 17 th century buildings and are the mortars connecting the elements of the wall. The buildings from which the mortars were sampled are listed in Table 1.

Table 1. Designation of samples and sampling locations

\begin{tabular}{|c|l|l|}
\hline Samples & \multicolumn{1}{|c|}{ Type of building } & \multicolumn{1}{c|}{ Built in } \\
\hline Z1 & St. Anne's Chapel in Pińczów & about 1600 \\
\hline Z2 & Collegiate Church in Klimontów & First half of 17th c \\
\hline
\end{tabular}

Photographs of the 17th century historic buildings are presented in Figures 1 and 2.
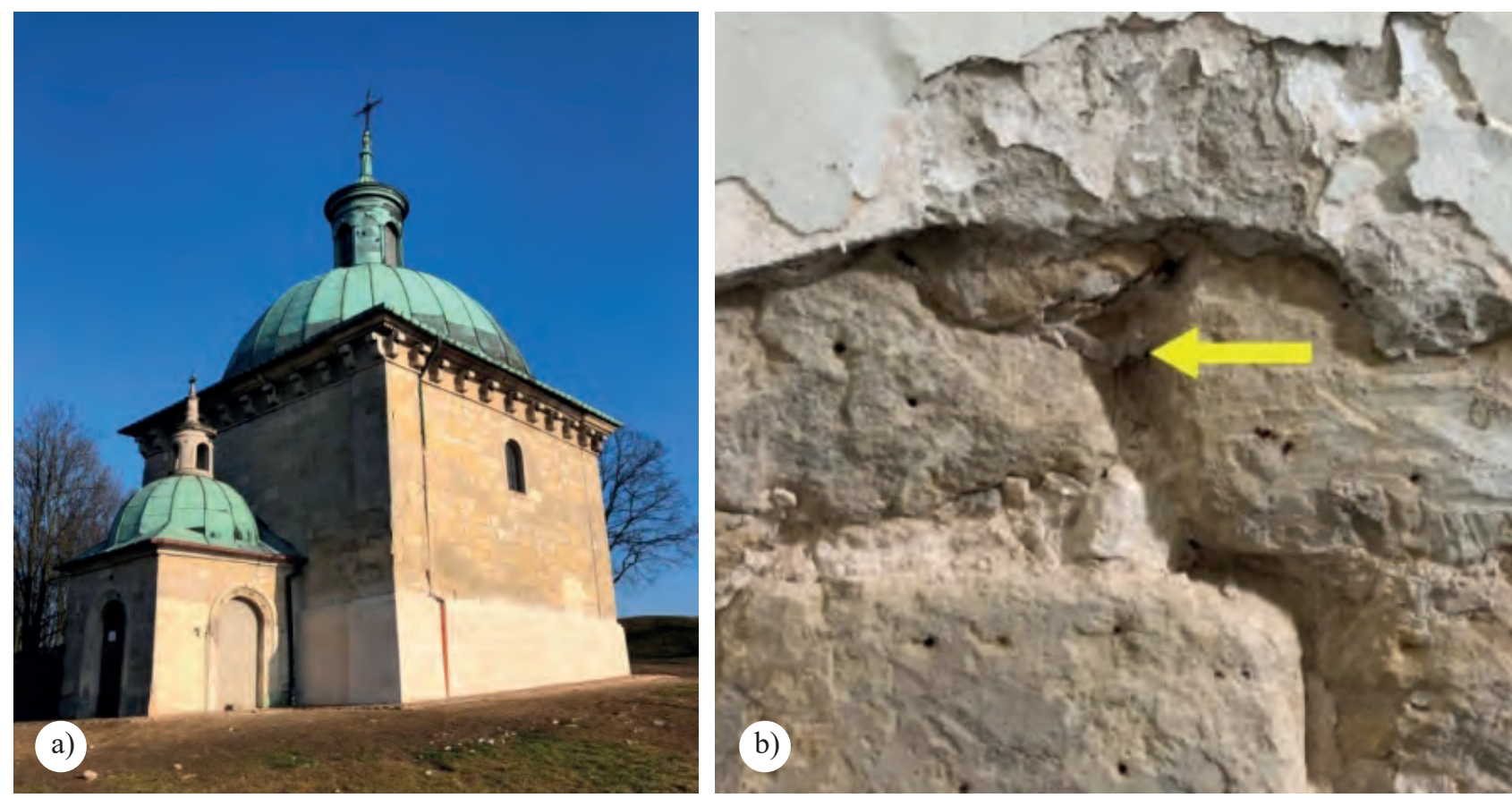

Fig. 1a) St Anne's Chapel in Pinczów, 1b) sampling location 


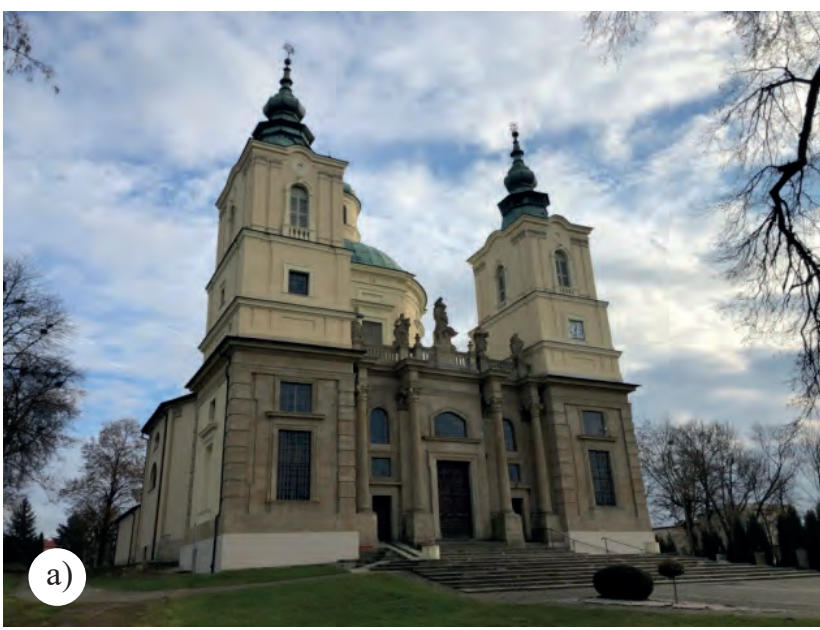

Fig. 2a) The church in Klimontów, 2b) sampling location

Figure 1a shows St Anne's Chapel in Pinczów. Designed by Santi Gucci, the chapel was built of local limestone (Pińczów limestone) in 1600 with a square body and a cupola. In the first half of the 19th century, a stone porch was added that mirrors the plan and shape of the main building. Due to its tangible and intangible meaning to the local community, the chapel has been renovated multiple times. In 2019 some remedial measures were applied, including the provision of horizontal insulation and drainage, and the repairs of the building base course. Figure $1 \mathrm{~b}$ shows the sampling locations on the eastern wall at a height of $1.5 \mathrm{~m}$ above the floor.

Another building from which the test samples were derived was the Collegiate Church in Klimontów (Fig. 2a). The temple founded by Jerzy Ossoliński and constructed in the years 1643-1650 mirrored the plan of the Vatican basilica. It was designed by Wawrzyniec Senes to the rejected Vignola's design of Il Gesú church from 1568. Destroyed by the Swedes in 1656, and then by the Cossacks of Prince Rakoczy, the church was saved from destruction by Inf. Walenty Boxa Radoszewski in the years 1721-58. The temple is baroque, made of stone and plastered with hewn details. The building was built on an ellipse plan with a screen facade, flanked by two towers topped with baroque cupolas. The samples were extracted from the vault of the underground part of the northern tower, at a height of $1.5 \mathrm{~m}$ above foundation level (Fig. 2b).

\subsection{Methods}

The tests were conducted using X-ray diffraction, thermal differential analysis and scanning microscope coupled with the detector of the energy dispersion spectrometer (EDS).

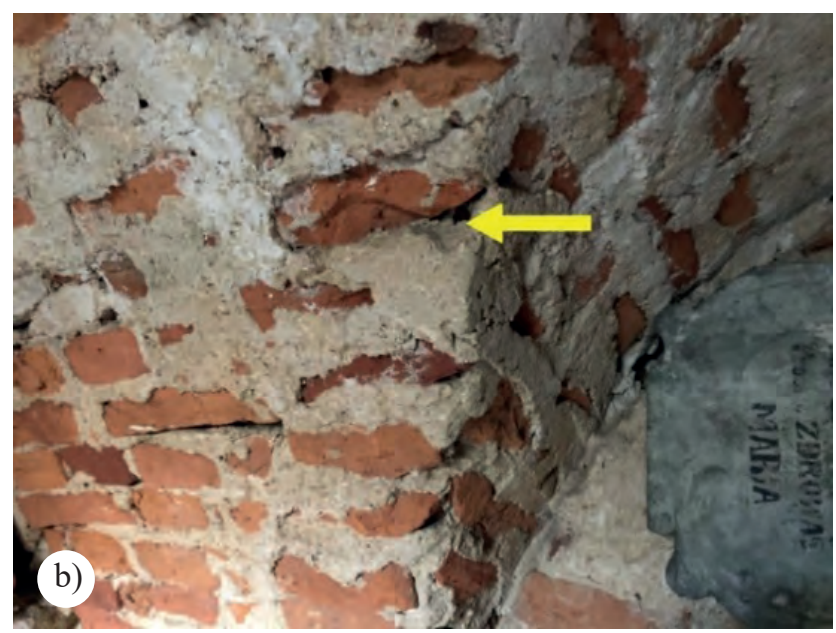

X-ray diffraction analysis was carried out using an Empyrean diffractometer (PANanalitical) in BraggBrentano geometry, $\mathrm{CuK} \alpha$ radiation with a wavelength of $\mathrm{k}=1.79026 \AA$, generated at $40 \mathrm{keV}$ and $20 \mathrm{~mA}$, in the range from $5-75^{\circ} 2 \Theta$, at the recording rate of $0.05^{\circ} 2 \Theta / \mathrm{s}$. The ICDD (International Center for Diffraction Data) database was used to analyse the recorded diffraction patterns.

The differential thermal analysis was performed in an SPT Q600 apparatus (TA INSTRUMENTS), 10 min, Tmax $1000^{\circ} \mathrm{C}$, under nitrogen atmosphere.

Selected mortar pieces were cut into $10 \mathrm{~mm}$ cubes, one side of which was hardened with resin and polished. The microstructure of the samples was examined on the specimens using an FEI COMPANY QUANTA FEG 205 scanning electron microscope equipped with an energy dispersion detector (EDS) spectrometer. The SEM-EDAX test was performed under low vacuum and accelerating voltages of $20 \mathrm{keV}$, beam current of $36 \mathrm{~mA}$, vacuum (column) pressure of $8.3 \times 10-8 \mathrm{mbar}$, sample pressure of $4.5 \times 10-6$ mbar, $400 \mathrm{~s}$ count time on EDS and $1 \mu \mathrm{m}$ beam size.

\section{RESULTS AND DISCUSSION}

The test results for the phase composition of mortars determined by the X-ray diffraction method and the image of the microstructure are shown in Figures 3 to 5 , respectively.

The results of the phase composition tests conducted using thermal differential analysis and $\mathrm{X}$-ray diffractometry indicate a $52 \%$ volume content of hardened, carbonated lime binder, a 30\% volume content of quartz sand with a varying particle size up to $0.5 \mathrm{~mm}$, and particles of organodetritic limestone up to $3 \mathrm{~mm}$ making up the remainder in the mortar from the 


\section{structure}

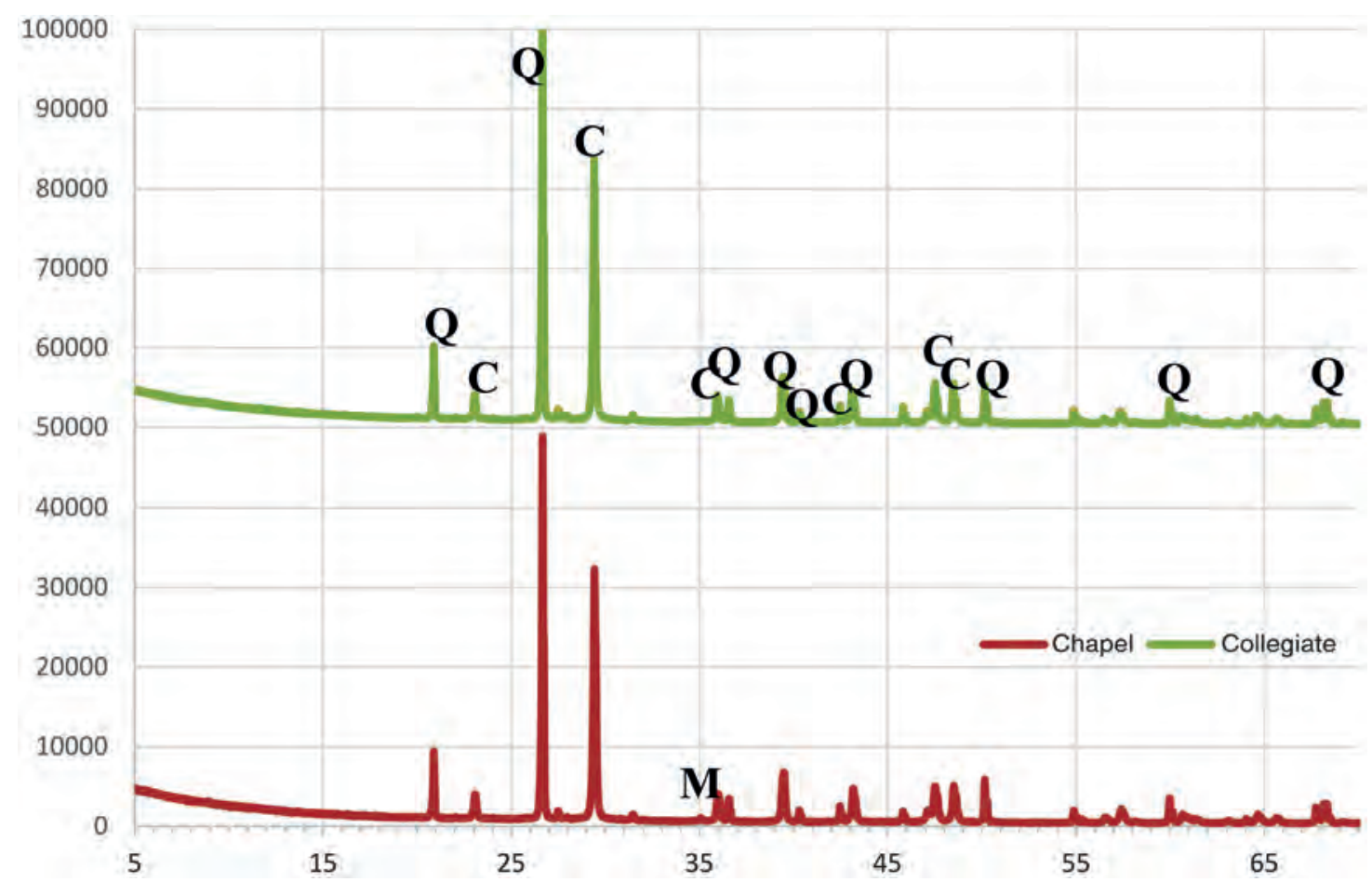

Fig. 3. X-ray photos of the mortar from St. Anne's Chapel in Pińczów and mortars from the Collegiate Church in Klimontów. Denotation: $Q$ - quartz, $C$-calcite, $M$-feldspar
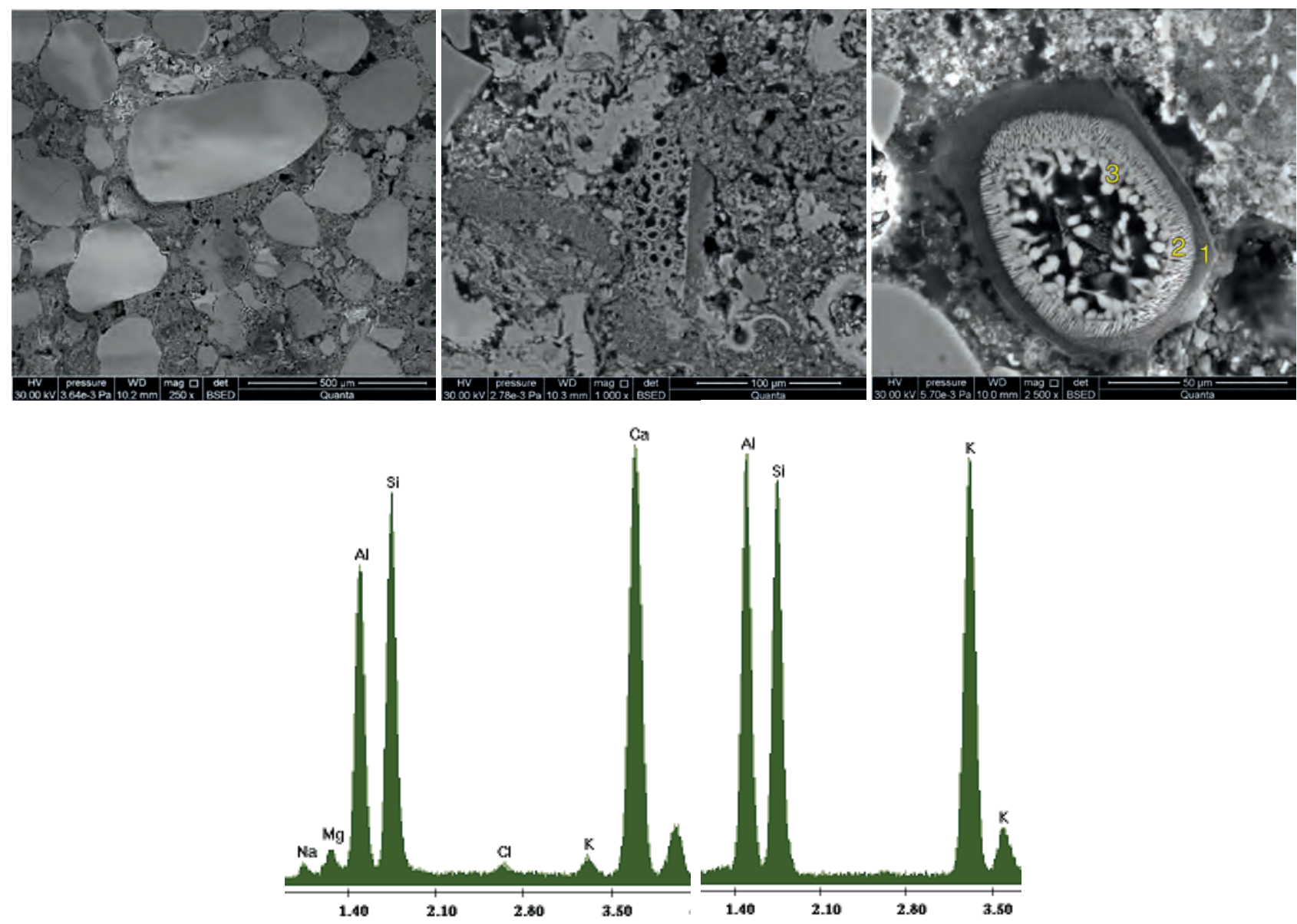

Fig. 4. Microstructure of the mortar extracted from St. Anne's Chapel in Pinczów 
wall of St. Anne's Chapel. The lime binder in the mortar from the collegiate wall in Klimontów makes up about $40 \%$ by volume and is composed of microcrystalline calcite. The aggregate is mainly quartz sand $(58 \%$ by volume). Other types of aggregates such as flint grains, feldspars and fine-grained sandstone with quartz-iron binder constitute about $2 \%$ by volume.

The microstructure image of the mortar derived from the wall of St. Anne's Chapel in Pińczów is shown in Figure 4. Quartz sand is the main constituent of the aggregate in the mortar. The grains are of various sizes up to $0.5 \mathrm{~mm}$. Limestone crumbs from the Pińczów rock make up the remainder. The binder is now fully carbonated lime with some clay as confirmed by the presence of potassium and calcium aluminosilicates.

Analysis of the microstructure of mortar samples from St. Anne's Chapel in Pińczów shows that it is a porous sand-lime mortar. The volume ratio of the binder to the aggregate is close to 1 . The quartz particle size ranges from 0.05 to about $0.5 \mathrm{~mm}$, with the predominant size in the range 0.1 to $0.5 \mathrm{~mm}$. Limestone shards from Pińczów stone are the second significant constituent represented by organodetritic varieties and single bioclasts. The sizes of the largest grains of organodetritic limestones are up to $3 \mathrm{~mm}$. Coated micrite limestone grains are usually less common. There are also flint grains and feldspar chunks. The binder is a hardened, carbonated lime paste, composed of microcrystalline calcite with a crystal size of about $1 \mu \mathrm{m}$. Figure 5 shows the microstructure image of the mortar derived from the Collegiate Church in Klimontów.

In this mortar, sand particles do not exceed $0.5 \mathrm{~mm}$, while the binder is fully carbonated calcium hydroxide, with a compact, microcrystalline structure. The mortar contains many voids and pores. In some of the pores, fungal hyphae are observed.

The tests of mortar samples from the Collegiate Church in Klimontów also show that it is a porous sand-lime mortar with a 2:3 binder to aggregate ratio. The aggregate consists of well-coated monocrystalline quartz particles ranging in size from 0.05 to about 0.6 $\mathrm{mm}$ with a predominance of 0.1 to $0.5 \mathrm{~mm}$ grains. The aggregate composition is complemented by limestone crumbs and brick fragments as well as less numerous flint grains, sandstone and feldspar crumbs. The crumbs of microsparite and micrite limestone crumbs, larger than the sand particles, are rounded to a varying extent and reach $5 \mathrm{~mm}$. The aggregate grains
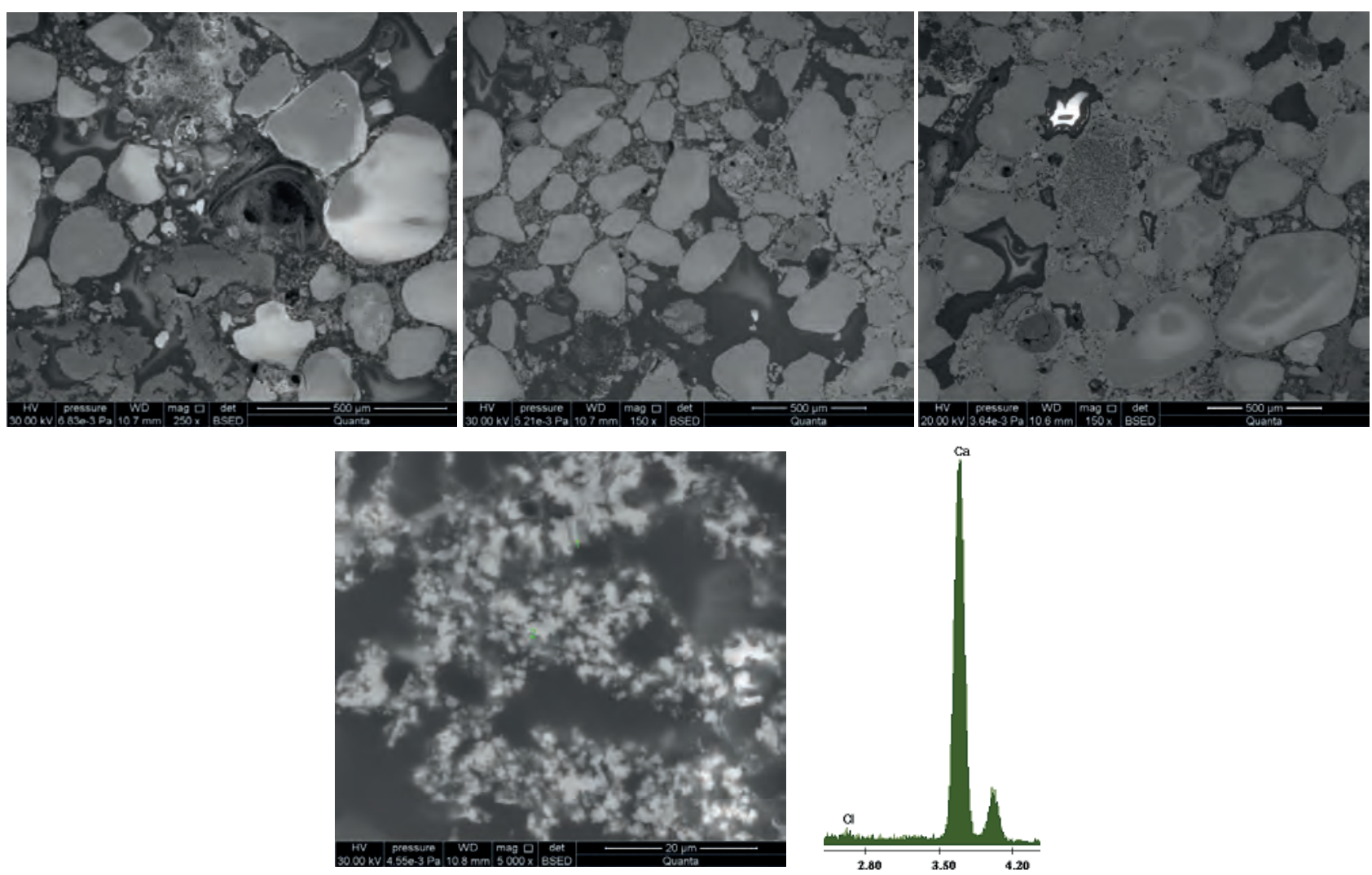

Fig. 5. Microstructure of the mortar extracted from the Collegiate Church in Klimontów 
are bonded with a hardened limestone paste composed of microcrystalline calcite with crystals of a few micrometres in size.

\section{SUMMARY}

The results of this study show that the materials bonding the elements of the wall in historic buildings are porous sand-lime mortars with an increased binder-to-aggregate ratio, also containing limestone crumbs, flints and feldspars, and fragments of bricks larger than sand particles. The binder is fully carbonated calcium hydroxide, with no pozzolanic additives. The results of the microstructure and phase composition tests of mortars used for bonding wall elements in buildings constructed at the end of the 16th and early 17th centuries can be used to select the composition of mortars used in the renovation and repair of historic buildings. As a supplement to the microstructure test results, tests of mortar porosity and their physical properties will be performed.

\section{REFERENCES}

[1] Kamionka L.: The issue of transience in architecture and the problems of conservation protection in the selected modernist buildings, Structure and Environment, 10 (2018), pp. 39-49, DOI 10.30540/sae-2018-004.

[2] Doroz-Turek M.: The determinants affecting the exhibition of architectural relics in a historical buildings, Structure and Environment, 9 (2017), pp. 165-179.

[3] Elsen J.: Microscopy of historic mortars - a review, Cement and Concrete Research, 36, (2006), pp. 1416-1424.

[4] Groot C.J.W.P., Bartos P.J.M., Hughes J.J.: Historic mortars: Characteristic and tests - concluding summary and state-of-the-art, Proc. Intern RILEM workshop, Advanced Concrete and Masonry Centre, University of Paisley, Scotland, 1999.

[5] Thomson M.L., Lindqvist J-E., Elsen J., Groot C.J.W.P.: Porosity of historic mortars, Proc. $13^{\text {th }}$ Intern. Brick and Block Masonry Conf., Amsterdam, 2004, pp. 1-10.

[6] Elsen J., Brutsaert A., Deckers M., Brulet R.: Microscopically study of ancient mortars from Tournai (Belgium), Materials Characterization, 53, (2004), pp. 289-295.

[7] Klimek B.: The method of research and structure analysis of the historic mortar. Part I - The macroscopic and microscopic - in visible light and electron microscopy (in Polish), Civil Engineering and Architecture, 11, (2012), pp. 113-120.

\section{Acknowledgement:}

The research leading to these results has been prepared under the topic Technology and improvement methods of the properties and durability of building composites No. 02.0.05.00/2.01.01.00.0000 SUB.BKTO.20.002. 